NOTE

\title{
A genetic fingerprint recapture technique for measuring growth in 'unmarkable' invertebrates: negative growth in commercially fished holothurians (Holothuria nobilis)
}

\author{
S. Uthicke' ${ }^{1}$, J. A. H. Benzie ${ }^{2}$ \\ ${ }^{1}$ Australian Institute of Marine Science, PMB No 3, Townsville, Queensland 4810, Australia \\ ${ }^{2}$ Centre for Marine and Coastal Studies, University of New South Wales, Sydney, New South Wales 2052, Australia
}

\begin{abstract}
A DNA fingerprinting technique based on amplified fragment length polymorphism (AFLP) was developed to identify individual bêche-de-mer (Holothuria nobilis) and analyse their growth in the wild. A size comparison of 74 individuals over two 6 mo periods and of 25 individuals over 12 mo showed that $1 \mathrm{~kg}$ individuals grew slowly (64 to $128 \mathrm{~g}$ annually). Larger holothurians (>1.5 kg) consistently decreased in weight, suggesting a plastic nature of weight in individual holothurians. This technique holds promise for ecological studies and for providing accurate data for the management of holothurians and other invertebrates that are difficult to tag.
\end{abstract}

KEY WORDS: Genetic tagging · DNA fingerprinting · Growth rates $\cdot$ Marine invertebrates $\cdot$ Bêche-de-mer

Resale or republication not permitted without written consent of the publisher

Fishery management often relies on mark-recapture techniques to obtain data on growth, migration and stock size. These data are vital to determine the population dynamics and ecology of fished species and to model likely responses of stocks and environment to fishing pressure. In some cases in which animals cannot be tagged, including soft-bodied marine invertebrates, it is difficult to obtain data for the determination of the population dynamic parameters needed for fishery management. Among these species are aspidochirotide holothurians, which are fished throughout the Indo-Pacific region as 'bêche-de-mer' (or 'trepang') for consumption and as an aphrodisiac for the Asian market. In extensive tagging experiments by Conand $(1989 b, c)$, tags were often rejected and recapture rates were generally low. Therefore, the only available

*E-mail: s.uthicke@aims.gov.au growth estimates have been obtained from a small number of individuals, or are based on indirect and imprecise techniques such as polymodal sizefrequency analysis (Shelley 1985, Conand 1989a, Uthicke 1994).

The lack of available data is one of the reasons for inadequate management of these species and for the breakdown in most bêche-de-mer fisheries throughout the Indo-Pacific (Conand 2001), including developed countries such as Australia (Uthicke \& Benzie 2000a). Overfishing and its secondary effect on the environment have been argued to be the primary humaninduced force in changing marine ecosystems (Jackson et al. 2001). Holothurians have important functions in nutrient remineralisation loops on coral reefs (Uthicke \& Klumpp 1998, Uthicke 2001a), and therefore reduced densities might have important side effects on the reef ecosystem.

Recent developments in PCR-based techniques have allowed the application of genetic techniques to new areas in ecology and management because of the low cost screening of large numbers of minute tissue samples. Several recent publications have reported genetic tagging in 'mark-recapture' experiments to estimate the population size of charismatic marine vertebrate species such as the humpback whale Megaptera novaeangliae (Palsboell et al. 1997), the pipefish Syngnathus floridae (Jones \& Avise 1997), and the painted turtle Chrysemys picta (Pearse et al. 2001). All these studies have used microsatellites as genetic markers, but these are often difficult to develop (Parker et al. 1998). Here, we introduce a method of reidentifying individual holothurians collected in situ using DNA fingerprinting based on amplified fragment length polymorphism (AFLP: Vos et al. 1995). This method has the advantage that it easily devel- 
oped, cost-efficient and is useful for individual identification because of to the high number of polymorphic sites (Mueller \& Wolfenbarger 1999). We also present first estimates of growth in the wild of one of the most valuable bêche-de-mer species (Uthicke \& Benzie 2000b). To our knowledge, this is the first study using genetic fingerprinting to measure growth rates.

Methods. Sample techniques: A total of 91 individuals of the high-value bêche-de-mer species Holothuria nobilis ('black teatfish': see comments on its taxonomy in Uthicke \& Benzie 2000a) were collected by snorkelling in May 2000 on the reef flats of Davies Reef $\left(18^{\circ} 50.1^{\prime} \mathrm{S}, 147^{\circ} 38.1^{\prime} \mathrm{E}\right)$ and Bowl Reef $\left(18^{\circ} 30.2^{\prime} \mathrm{S}\right.$, $\left.147^{\circ} 32.8^{\prime} \mathrm{E}\right)$, in the central section of the Great Barrier Reef (GBR). The holothurians were brought onboard a research vessel and kept in flowing (60 l) seawater containers. Individuals were weighed using a spring balance (Salter Super Samson, $\pm 25 \mathrm{~g}$ ) after a minimum time of 5 min outside the water to minimise the amount of water retained in their respiratory trees. Repeated measurements of 20 individuals showed that the measurements had an average coefficient of variation of $5.8 \%$ of the mean. This variation is assumed to have resulted mainly from variation in the amount of seawater retained in the water lungs.

A small tissue biopsy (approximately $1 \mathrm{~g}$ ) was taken from the ventral epidermis of each individual and preserved in $100 \%$ ethanol for later DNA fingerprint analysis. Tissue samples from the first sampling time were snap-frozen in liquid nitrogen and subsequently stored at $-70^{\circ} \mathrm{C}$. However, later tests showed that amplification success is higher with ethanol preserved samples (see 'Results'). The holothurians were carefully returned to an area on the back reef of Davies Reef that had been previously cleared of all Holothuria nobilis detected during a $2 \mathrm{~h}$ search.

In November 2000, approximately 6 mo later, we returned to this area and collected 89 individuals in an area of up to $150 \mathrm{~m}$ distance on either side of the release position. These were all individuals encountered during a $6 \mathrm{~h}$ search by manta tows. The holothurians were weighed, a tissue sample was taken, and they were released as described above. In May 2001, 1 yr after the initial samples had been obtained, the procedure was repeated a third time, collecting all 81 individuals detected in about $4 \mathrm{~h}$. The exact densities in the sample area were not measured; however, largescale studies of over 20 reefs in the same area of the GBR suggested that densities on unfished reefs are over 20 ind. ha ${ }^{-1}$ (Uthicke \& Benzie 2000a).

DNA fingerprinting: DNA extractions of epidermal holothurian tissue were performed using Quiagen DNeasy extraction kits following the instructions of the manufacturer. However, repeatability of the amplifications was greatly improved by reducing the initial amount of tissue to $10-20 \mathrm{mg}$, using twice the recommended amount of proteinase, and performing an extra cleaning step using CL 6B (Sepharose ${ }^{\mathrm{TM}}$ ) spincolumns prepared with acid-washed glass beads.

DNA fingerprints from each individual were obtained using the amplified fragment length polymorphism (AFLP) technique following general procedures described by Vos et al. (1995), with some variations as described by Wilson et al. (2002). Genomic DNA (100 ng) was digested with ECoRI and MSEI, followed by ligation of respective adapters in a $50 \mu \mathrm{l}$ reaction volume. $1 \mu \mathrm{l}$ of these ligations were used directly in $20 \mu \mathrm{l}$ pre-amplifications using primers with a single selective base. EcoRI-AAG and MseI-CGT were used as selective primers in the second amplification step after initial tests indicated that the combination of $2 \times 3$ selective bases yielded an appropriate amount of bands with variation. The ECoRI-AAG primer was endlabelled with ${ }^{33} \mathrm{P}$, and amplification products were electrophoresed for $2.5 \mathrm{~h}$ on a $5 \%$ denaturing acrylamide gel, and later visualised through exposure to film (Kodak, BioMax). The primers resulted in approximately 80 bands in the well resolved range between 100 and 480 nucleotides (Fig. 1). Out of these bands, we chose 31 that were polymorphic and could be reliably scored, as tested by repeated extractions and subsequent amplifications of 20 individuals. The presence or absence of each of these bands was scored for each individual to form a DNA fingerprint. Every individual was scored twice in 2 independent selective amplifications. Several individuals that had distinctly fewer bands than all other individuals were deemed as not successfully amplified and were discarded from further analyses. Based on the frequency of each band, we calculated the probability of identity $\left(P_{\mathrm{ID}}\right.$, Waits et al. 2001) using the conservative formula for high occurrence of siblings and inbreeding.

Growth model: Initial data analyses comparing weights on 1 sample occasion with the weight 6 mo later indicated that commonly used growth functions (e.g. von Bertalanffy, Richards or Tanaka, see Ebert 1999 for details) which assume asymptotic growth or continuous low growth rates of large individuals did not fit the data. Instead, large individuals appeared to shrink in many cases. Therefore we chose Francis' (1995) mark-recapture analogue of Schnute's (1981) growth model to fit the data using a Basic program provided by Ebert (1999) based on the Simplex algorithm. Francis' model is based on 5 parameters. The first $2\left(\lambda_{1}\right.$ and $\left.\lambda_{2}\right)$ are arbitrary and chosen by the user to represent individuals from the lower and upper ends of the range of observed sizes; we have chosen 1.0 and $2.5 \mathrm{~kg}$. The third and fourth parameters $\left(g_{1}\right.$ and $g_{2}$ ) represent predicted mean annual growth rates at $\lambda_{1}$ and $\lambda_{2}$, respectively. The fifth parameter (b) 
has no simple biological meaning and '... may be thought of as describing curvature in the model...' (Francis 1995). A derived parameter (c), is also presented here because, when raised to the power of $1 / b$, it is similar (but not biologically equivalent) to the asymptotic weight $\left(W_{\infty}\right)$ of von Bertalanffy-like growth functions (Francis 1995). In the case of negative growth of larger individuals, $C^{1 / \mathrm{b}}$ marks the point of zero growth, e.g. smaller individuals grow whereas larger ones shrink.

Results and discussion. AFLP analyses using 1 primer combination yielded individual DNA fingerprints for each Holothuria nobilis successfully amplified within each sampling period. The proportion of samples that were successfully amplified $(79 \%)$ was smaller for samples obtained at the first time collection and which had been snapfrozen than in the second $(87 \%)$ and third $(100 \%)$ collections. Samples from later sampling periods were preserved in $100 \%$ ethanol and this appeared to improve amplification success (Table 1).

Among the samples collected in November 2000, 27 had fingerprints identical to those observed in tissues collected during the previous time period (Table 1). Similarly, 37 samples collected in May 2001 matched samples from November 2000, and 25 samples were the same as $1 \mathrm{yr}$ prior to that. Based on the frequency of each band in the sample from the first time period, the probability of identity $\left(P_{\mathrm{ID})}\right.$ is less than 0.01 (i.e. 0.007). Therefore, all individuals in the second and third samples with the same fingerprints as individuals from the first or second samples were accepted as being the same individuals.

Although variation is considerable, a large proportion (53 to $65 \%$ ) of the weight in recaptured individuals can be predicted by the weight of the initial sample using Francis' growth model (Table 2, Fig. 2). Smaller $(1.0 \mathrm{~kg})$ individuals were predicted (Parameter $g_{1}$ : Table 2) to grow between 64 and $148 \mathrm{~g}$ annually, with

\section{A}

B

B A

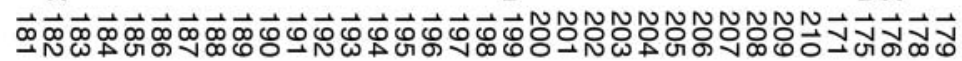

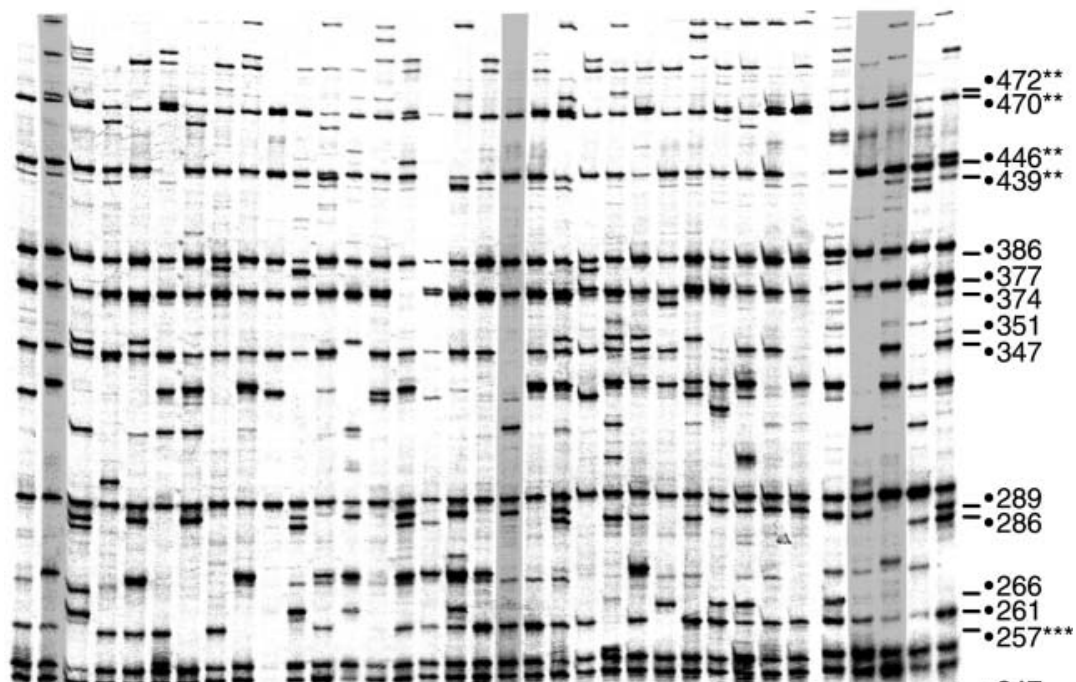

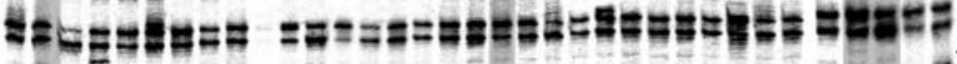

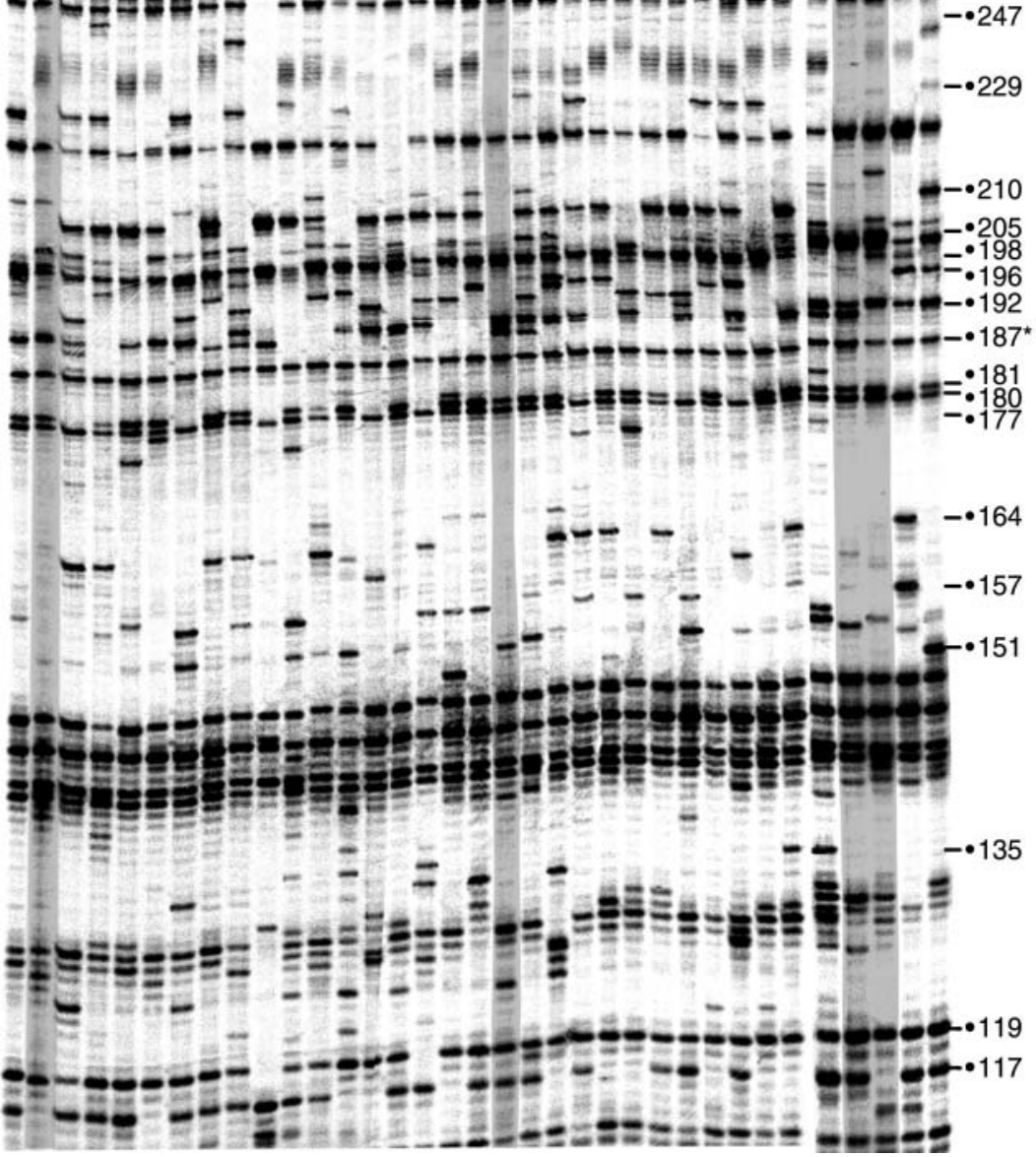

Fig. 1. Holothuria nobilis. AFLP gel indicating 31 variable markers in 30 individuals sampled from Davies Reefs in November 2000 (Samples 181 to 210) and 5 individuals sampled in May 2000 (Samples 171 to 179). Highlighted samples 176 and $182(\mathrm{~A})$, and 175 and 199 (B), have identical fingerprints and were identified as matches. The size of each marker (numbers of base pairs) is given on the right. *Band is not variable on this gel $^{*}{ }^{*}$ sizes of the upper 4 markers are approximated $; * *$ band does not appear on the gel 
Table 1. Holothuria nobilis. Number and (percentage) of individuals collected, successfully amplified and matched with previous samples

\begin{tabular}{|c|c|c|c|c|c|c|c|c|c|}
\hline \multicolumn{2}{|c|}{ Period S1 (May 2000) } & \multicolumn{3}{|c|}{ Period S2 (Nov. 2000) } & \multicolumn{5}{|c|}{ Period S3 (May 2001) } \\
\hline $\begin{array}{c}\text { No. } \\
\text { collected }\end{array}$ & $\begin{array}{l}\text { No. } \\
\text { amplified }\end{array}$ & $\begin{array}{c}\text { No. } \\
\text { collected }\end{array}$ & $\begin{array}{c}\text { No. } \\
\text { amplified }\end{array}$ & $\begin{array}{l}\text { Matches } \\
\text { with S1 }\end{array}$ & $\begin{array}{c}\text { No. } \\
\text { collected }\end{array}$ & $\begin{array}{c}\text { No. } \\
\text { amplified }\end{array}$ & $\begin{array}{l}\text { Matches } \\
\text { with S1 }\end{array}$ & $\begin{array}{l}\text { Matches } \\
\text { with S2 }\end{array}$ & $\begin{array}{l}\text { Matches with } \\
\text { S1 and S2 }\end{array}$ \\
\hline 91 & $72(79 \%)$ & 89 & $77(87 \%)$ & 27 & 81 & $81(100 \%)$ & 25 & 37 & 18 \\
\hline
\end{tabular}

somewhat higher rates when modelled from data obtained between November and May. Individuals of $2.5 \mathrm{~kg}$, however, were consistently predicted (Parameter $g_{2}$ : Table 2) to shrink more than $600 \mathrm{~g}$. The weight of zero growth was around 1.5 to $1.6 \mathrm{~kg}\left(c^{1 / \mathrm{b}}\right.$, Table 2).

The lack of small individuals in the dataset means it is impossible to predict the age of holothurians in the size range observed. However, even if small individuals grow 3 times as fast as predicted for $1 \mathrm{~kg}$ individuals recaptured after $1 \mathrm{yr}$ in this study $(81 \mathrm{~g} \times 3=243 \mathrm{~g})$, animals of $1 \mathrm{~kg}$ would be older that $4 \mathrm{yr}$. Using modal

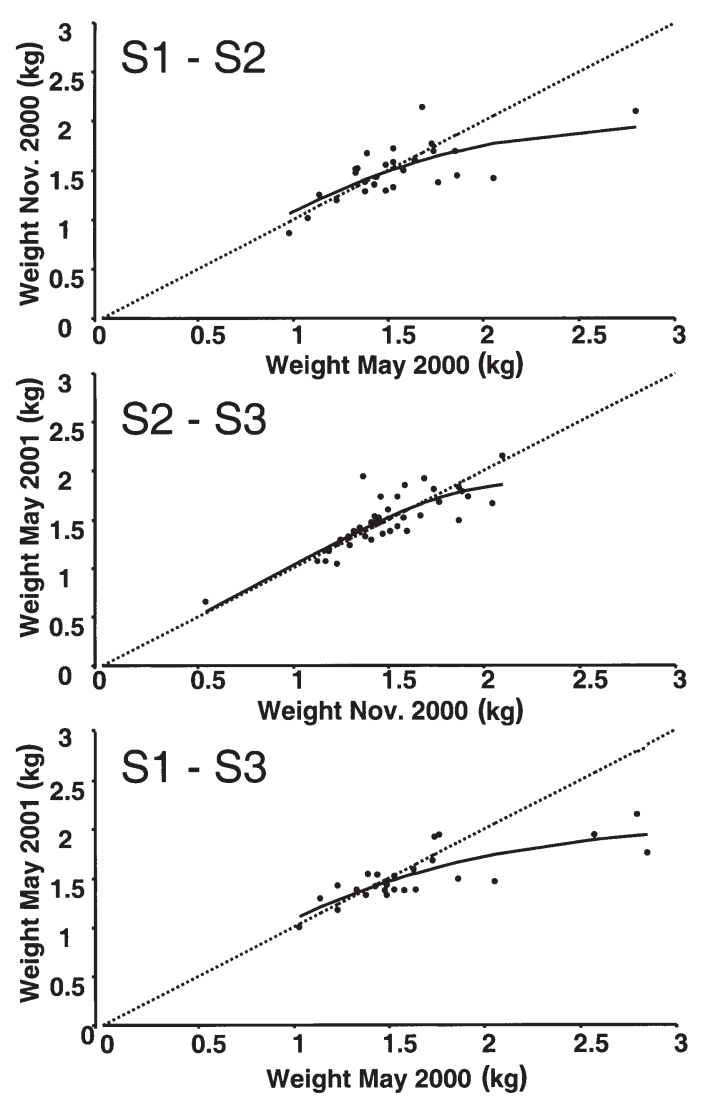

Fig. 2. Holothuria nobilis. Initial versus final weight of recaptured individuals between May 2000 and November 2000 (S1-S2), November 2000 and May 2001 (S2-S3), and May 2000 and 2001 (S1-S3). Broken lines indicate hypothetical lines of zero growth, solid lines are fitted with Francis' (1995) analogue of Schnute's (1981) growth model. (•) Original data points progression analysis, large individuals of other large holothurian species (with weights higher than $3 \mathrm{~kg}$ ) have been estimated to be older than $10 \mathrm{yr}$ (Conand 1989a). The growth estimates obtained here for $1.0 \mathrm{~kg}$ holothurians are similar to those obtained in studies on smaller species - these ranged between 100 and $200 \mathrm{~g}$ $\mathrm{yr}^{-1}$ (Franklin 1980, Chao et al. 1994, Uthicke 1994). However, growth rates obtained here are low compared to those of other large holothurian species, which have been suggested to grow up to $450 \mathrm{~g} \mathrm{yr}^{-1}$ (Conand 1989a,b,c, Shelley 1985).

The finding that the larger individual Holothuria nobilis consistently shrink was unexpected. It is known that holothurians shrink in aquaria (Conand 1983, Shelley 1985, Wiedemeyer 1992), but this has never been reported of populations in situ. Negative growth has also been inferred for other echinoderms, such as echinoids by Ebert (1967), who suggested that their size could be controlled by environmental conditions. It may be that the environmental conditions were not favourable in the year the present study was conducted. Alternatively, the number of holothurians transplanted to the study side may have been in excess of the carrying capacity of the habitat. Although densities were not measured, they were inferred to be within, albeit at the higher end of, the range naturally occurring on the GBR (Uthicke \& Benzie 2000a, Uthicke unpubl. data). Because the holothurians shrank most distinctly over the period of $1 \mathrm{yr}$, it appears unlikely that weight changes are caused by seasonal sexual reproduction such as changes in the gonado-somatic index. In either case, the shrinkage of large individuals

Table 2. Holothuria nobilis. Parameters of Francis' (1995) growth function. $g_{1}, g_{2}$ : predicted mean annual growth rates at lower and upper ends of observed sizes, $b$ : curvature in the model; $C^{1 / b}$ : derived parameter similar to asymptotic weight

\begin{tabular}{|lccc|}
\hline $\begin{array}{l}\text { Growth } \\
\text { parameters }\end{array}$ & $\begin{array}{c}\text { May 2000- } \\
\text { Nov 2000 }\end{array}$ & $\begin{array}{c}\text { Nov 2000- } \\
\text { May 2001 }\end{array}$ & $\begin{array}{c}\text { May 2000- } \\
\text { May 2001 }\end{array}$ \\
\hline $\mathrm{N}$ & 27 & 37 & 25 \\
$\mathrm{R}^{2}$ & 0.53 & 0.68 & 0.65 \\
$g_{1}\left(\mathrm{~kg} \mathrm{yr}^{-1}\right)$ & 0.148 & 0.064 & 0.081 \\
$g_{2}\left(\mathrm{~kg} \mathrm{yr}^{-1}\right)$ & -0.794 & -0.703 & -0.629 \\
$b$ & -3.452 & -8.508 & -2.669 \\
$c^{1 / b}$ & 1.4 & 1.63 & 1.40 \\
\hline
\end{tabular}


strongly suggests that the average weight of holothurians in the wild is highly plastic and that their density, size and biomass may be limited and regulated by food supply, as previously suggested (Uthicke 1997, 2001b).

Holothurian fisheries are currently good examples of boom-and-bust fisheries. Recent drastic declines in catches and shifts towards less valuable species (Conand 2001) indicate that the boom period has reached its end in many Indo-Pacific countries. Hardly any juvenile or small $(<1000 \mathrm{~g})$ individuals were found during our study. The scarcity of juveniles is a common phenomenon in studies on holothurians (e.g. Uthicke 2001b). This may indicate that recruitment of juveniles is very sporadic, which, in addition to the suggested slow growth rates would predict very slow recovery of overfished stocks. We have demonstrated that it is possible to recapture and identify a sufficient number of individuals to obtain growth rates for marine animals that are otherwise difficult to tag. It was not possible here to present complete growth curves because small individuals or new recruits were never observed. Complete growth curves will be developed over time and once data from several study areas become available. Apart from growth studies, we believe that similar studies with slightly different experimental designs will be possible in future to estimate migration rates, population size and recruitment. Given the high reliability and low effort involved in developing AFLP fingerprints relative to other markers such as microsatellites (Mueller \& Wolfenbarger 1999), the methods discussed here may prove a useful approach to increasing knowledge on the ecology of benthic animals. We are optimistic that application of this tool will allow improved management of bêche-de-mer and other invertebrate fisheries.

Acknowledgements. We are grateful to M. Brown, B. Schaffelke and D. Welsh for field assistance during collections. The latter and M. Schubert also assisted in the laboratory analyses. The MS was greatly improved by the comments of 4 anonymous reviewers. This is contribution No. 1106 of the Australian Institute of Marine Science.

\section{LITERATURE CITED}

Chao SM, Chen CP, Alexander PS (1994) Reproduction and growth of Holothuria atra (Echinodermata: Holothuroidea) at two contrasting sites in southern Taiwan. Mar Biol 119: $565-570$

Conand C (1983) Methods of studying growth in holothurians (bêche-de-mer), and preliminary results from a bêche-demer tagging experiment in New Caledonia. SPS Fish Newsl 26:31-38

Conand C (1989a) Comparison between estimations of growth and mortality of two stichopodid holothurians:
Thelenota ananas and Stichopus chloronotus (Echinodermata: Holothuroidea). In: Choat JA et al. (eds) Proc 6th Int Coral Reef Symp, Townsville, 2:661-665

Conand C (1989b) Growth and mortality of some holothurians from the lagoon of New-Caledonia. In: Regis MB, Segui A, Frason C, Escoubet P, Riva A (eds) Proceedings of the Sixth International Symposium on Echinodermata. AA Balkema, Rotterdam, p 661-665

Conand C (1989c) Les holothuries aspidochirotes du lagon de Nouvelle-Calédonie: biologie, écologie et exploitation. Etudes et thèse ORSTOM, Paris

Conand C (2001) Overview over the last decade of sea cucumber fisheries-what possibilities for a durable management? In: Barker M (ed) Echinoderms 2000, Proceedings of the 10th International Echinoderm Conference, Dunedin, New Zealand. AA Balkema, Rotterdam, p 339-344

Ebert TA (1967) Negative growth and longevity in the purple sea urchin Strongylocentrotus purpuratus (Stimpson). Science 157:557-558

Ebert TA (1999) Plant and animal populations methods in demography. Academic Press, San Diego

Francis R ICC (1995) An alternative mark-recapture analogue of Schnute's growth model. Fish Res (Amst) 23:95-111

Franklin SE (1980) The reproductive biology and some aspects of the population ecology of the holothurians Holothuria leucospilota (Brandt) and Stichopus chloronotus (Brandt). $\mathrm{PhD}$ thesis, University of Sydney

Jackson JBC, Kirby MX, Berger WH, Bjorndal KA and 15 others (2001) Historical overfishing and the recent collapse of coastal ecosystems. Science 293:629-637

Jones AG, Avise JC (1997) Polygynandry in the dusky pipefish Syngnathus floridae revealed by microsatellite DNA markers. Evolution 51:1611-1622

Mueller UG, Wolfenbarger LL (1999) AFLP genotyping and fingerprinting. Trends Ecol Evol 14:389-394

Palsboell PJ, Allen J, Berube M, Clapham PJ and 15 others (1997) Genetic tagging of humpback whales. Nature 388: 767-769

Parker PG, Snow AA, Schug MD, Booton GC, Fuerst PA (1998) What molecules can tell us about populations: choosing and using a molecular marker. Ecology 79: 361-382

Pearse DE, Eckerman CM, Janzen JJ, Avise JC (2001) A genetic analogue of 'mark-recapture' methods for estimating population size: an approach based on molecular parentage assessments. Mol Ecol 10:2711-2718

Schnute J (1981) A versatile growth model with statistical stable parameters. Can J Fish Aquat Sci 38:1128-1140

Shelley CC (1985) Growth of Actinopyga echinites and Holothuria scabra (Holothurioidea: Echinodermata) in Papua New Guinea. Proc 5th Int Coral Reef Congr 5: 297-230 (Gabrié C, Harmelin VM [eds] Antenne Museum -EPHA, Moorea, French Polynesia)

Uthicke S (1994) Distribution patterns and growth of two reef flat holothurians, Holothuria atra and Stichopus chloronotus. In: David B, Guille A, Féral JP, Roux M (eds) Echinoderms through time: Proceedings of the 8th International Echinoderm Conference, Dijon. AA Balkema, Rotterdam, p 569-576

Uthicke S (1997) The seasonality of asexual reproduction in Holothuria (Halodeima) atra, Holothuria (Halodeima) edulis and Stichopus chloronotus (Holothuroidea: Aspidochirotida) on the Great Barrier Reef. Mar Biol 129:435-441

Uthicke S (2001a) Interactions between sediment-feeders and microalgae on coral reefs: grazing losses versus production enhancement. Mar Ecol Prog Ser 210:125-138 
Uthicke S (2001b) The influence of asexual reproduction on the structure and dynamics of Holothuria (Halodeima) atra and Stichopus chloronotus populations of the Great Barrier Reef. J Mar Freshw Res 52:1-11

Uthicke S, Benzie JAH (2000a) The effect of bêche-de-mer fishing on densities and size structure of Holothuria nobilis (Echinodermata: Holothurioidea) populations on the Great Barrier Reef. Coral Reefs 19:271-276

Uthicke S, Benzie JAH (2000b) Allozyme electrophoresis indicates high gene flow between populations of Holothuria nobilis (Holothuroidea: Aspidochirotida) on the Great Barrier Reef. Mar Biol 137:819-825

Uthicke S, Klumpp DW (1998) Microbenthos community production in sediments of a near shore coral reef: seasonal variation and response to ammonium recycled by holothurians. Mar Ecol Prog Ser 169:1-11

Editorial responsibility: Otto Kinne (Editor),

Oldendorf/Luhe, Germany
Vos P, Hogers R, Bleeker M, Reijans M and 7 others (1995) AFLP: a new technique for DNA fingerprinting. Nucleic Acids Res 23:4407-4414

Waits LP, Luikart G, Taberlet P (2001) Estimating probability of identity among genotypes in natural populations: caution and guidelines. Mol Ecol 10:249-256

Wiedemeyer WL (1992) A basic study on the morphology, physiology and the behavioural ecology of small juveniles of the holothuria species Actinopyga echinites (Jäger 1833) with respect to stock enhancement of tropical holothurians. Master thesis, University of Ryukyus, Japan

Wilson K, Li Y, Whan V, Lehnert S and 10 others (2002) Genetic mapping of the black tiger shrimp Penaeus monodon with amplified fragment length polymorphisms. Aquaculture 204:297-309

Submitted: February 8, 2002; Accepted: May 7, 2002

Proofs received from author(s): September 6, 2002 